\title{
EXPERIMENTAL STUDY ON SWISS WHITE MICE TO EVALUATE THE ANTIANXIETY EFFECT OF COMMON WILD FIG EXTRACT (FICUS THONNINGII)
}

\author{
ADUEMA WADIONI* \\ Department of Human Physiology, Faculty of Basic Medical Sciences, PAMO, University of Medical Sciences, Port Harcourt, Nigeria. \\ Email: Wadioniaduema@gmail.com.
}

Received: 9 November 2018, Revised and Accepted: 21 December 2019

\section{ABSTRACT}

Objective: Since prehistoric times, man has relied on herbal plants as a source of medicine in curing various ailments. This study was carried out to assess the antianxiety-like effect of the ethanol extract of wild fig (Ficus thonningii) in Swiss white (CD-1) mice.

Methods: Thirty Swiss mice were randomly divided into three groups (1-3) (n=10). Group 1 (control) was administered normal rat fed and saline while Group 2 (low dose) and Group 3 (high dose) were administered $10 \mathrm{mg} / \mathrm{kg} \mathrm{w} / \mathrm{w}$ and $20 \mathrm{mg} / \mathrm{kg} \mathrm{w} / \mathrm{w}$ of the plant extract, respectively. The elevated plus maze was used to assess anxiety-related behaviors.

Results: Data were analyzed using the statistical tools (one-way ANOVA and student t-test). Results revealed anxiety-like behavior in the low- and high-dose-treated mice when compared to the control.

Conclusion: Therefore, administration of F. thonningii reduced an anxiety-like behavior in mice.

Keywords: Ficus thonningii, Elevated plus maze, Anxiety, Mice.

(C) 2020 The Authors. Published by Innovare Academic Sciences Pvt Ltd. This is an open access article under the CC BY license (http:/ / creativecommons.org/ licenses/ by/ 4.0/ ) DOI: http:/ / dx.doi.org/ 10.22159/ ijms.2019.v7i1.29357

\section{INTRODUCTION}

Since prehistoric times, mankind has relied on plants as a source of food, shelter, and medicine [1]. Before the invention of allopathic medicine, man used plant medicines for curing ailments [2]. Today, apart from their commercial exploitation in manufacturing, cosmetic, and pharmaceutical industries, plants are still extensively used in ethnomedical and ethnoveterinary practice. Plant-based medicines have also contributed significantly to the development of conventional drugs. One of the such plants is Ficus thonningii. F. thonningii is a species of Ficus. It is native to Africa. Recent phylogenetic analysis suggests that several distinct species may be classified as $F$. thonningii. F. thonningii is a multistemmed tree of the Moraceae family. It is a fruit-bearing tree that has been used traditionally for treating diseases. The tree is mainly distributed in the upland forests of tropical and subtropical Africa, and it grows best in light, deep, and well-drained soil [3]. The leaves have been used traditionally to treat diarrhea, gonorrhea, diabetes mellitus [4], bronchitis, urinary tract infections [5], mental illness [6], bone movement disorders, ringworm, thrush, scabies, and athlete's foot rot [7]. F. thonningii exudes white, sticky latex that turns pinkish with time [8]. The latex has been traditionally used for treating fever, tooth decay, and ringworm [8] and cataract in the eye [7] and as a vermifuge [9]. The roots of the plant have been reportedly used for preventing miscarriages and for stopping nosebleeding [10]. In addition, the roots are also used for relieving stomach pains, diarrhea, and pneumonia and chest pains $[4,11]$. Stem bark extract of $F$. thonningii is commonly used for the treatment of sore throat, arthritis, diarrhea, and ulcers [11] and to enhance fertility. It is a traditionally important plant species with both nutritional and therapeutic benefits. Commonly known as the common wild. The fruits which are about $10-20 \mathrm{~mm}$ in diameter are usually yellow, turning pinkish when ripe [3]. A full botanical and taxonomic description and a detailed review of the nutritional benefits, phytochemical content, and pharmacological properties of $F$. thonningii have been reported. The stem bark is used for treating colds, arthritis, inflammation, pneumonia, bronchitis, diarrhea, constipation, and bowel disorders and to stimulate lactation [11-14]. F. thonningii roots are used for treating malaria, fever, and hepatitis, preventing miscarriages, and stopping bleeding $[1,10]$. In spite of the various measures of treatment and prevention of anxiety and fear, as well as other behavioral changes, they still remain a major problem. Therefore, most researchers have resorted to traditional medicine to solve this problem.

\section{METHODS}

Animals

Thirty adult male mice weighing between 17 and $22 \mathrm{~g}$ from animal room of the Department of Physiology, Abia State University, were used for this research work. These animals were kept in the animal room of the Department of Physiology, Abia State University, and were fed for 2 weeks with clean drinking water for acclimatization. All rules applying to animal safety and care were observed. 2 weeks were used for chronic administration of the plant extract before the experiments procedure was started.

\section{Experiment procedures}

The mice were 30 in numbers and were grouped into three groups, and each group contains 10 mice. Group 1 was the control group; Group 2 was the low dose, while Group 3 was the high dose.

\section{DRUG ADMINISTRATION}

The $\mathrm{LD}_{50}$ of the plant (F. thonningii) was first established for the mice and the drugs were administered orally for 2 weeks using an oral cannula, the low dose was given $10 \mathrm{mg} / \mathrm{kg}$ of the extract each day, and the high dose was given $20 \mathrm{mg} / \mathrm{kg}$ each day. The control groups were isolated and drugs were not administered to them.

\section{Ethical approval}

I hereby declare that the principle of laboratory animal care was followed. All animals have been examined and approved by the appropriate Ethics Committee.

\section{APPARATUS AND EXPERIMENTAL PROTOCOLS}

Elevated plus maze (EPM)

The EPM setup was built according to the description of Lister [15] as reported by John [16]. The apparatus is in the configuration of a "+," 
and comprised two open arms $(50 \mathrm{~cm} \times 10 \mathrm{~cm})$ across each other and perpendicular to two closed arms $(50 \mathrm{~cm} \times 10 \mathrm{~cm} \times 20 \mathrm{~cm})$ with a central platform $(10 \mathrm{~cm} \times 10 \mathrm{~cm})$. The closed arms had a high $(20 \mathrm{~cm})$ wall to enclose the arm. The entire apparatus was $50 \mathrm{~cm}$ above the floor. The apparatus was made of wooden materials, painted black.

\section{Experimental procedures}

Mice were placed in the central square of the plus maze facing the open arm and were then allowed to explore the apparatus for $5 \mathrm{~min}$. The maze was then cleaned with methylated spirit and allowed to dry between tests.

\section{Behaviors scored were as follows}

- Stretch-attend posture: Frequency with which the animal demonstrates forward elongation of the head and shoulders followed by retraction to the original position.

- Rearing: Frequency with which the animal stands on its hind legs.

- Grooming: Frequency and duration of time that the animal spent licking or scratching itself while stationary.

- Defecation: Number of fecal bole produce.

- Closed arm entries: Frequency with which the animal enters the closed arms. All four of the mouse paws should be in the closed arms to be regarded as an entry.

- Open arm: Time that the animal spent in the open arms.

- Closed arm: Time that the animal spent in the closed arms.

- Head dipping: Frequency with which the animal lowered its head over the sides of the open arms toward the floor.

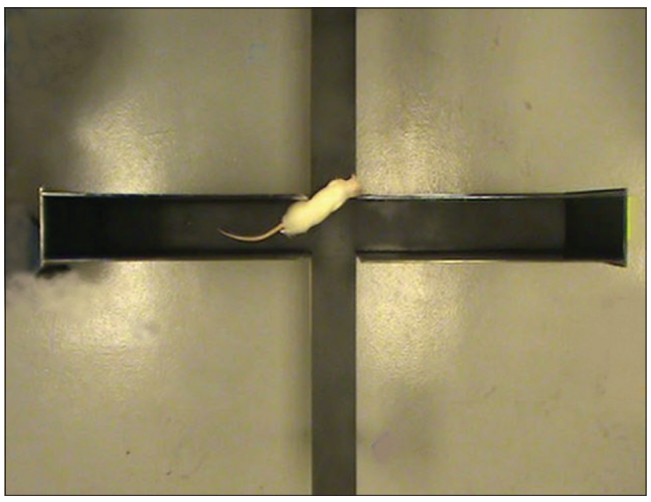

\section{EPM APPARATUS}

\section{Statistical analysis}

Values were shown as mean \pm standard error of mean. Testing method includes one-way ANOVA, followed by post hoc. $\mathrm{p}<0.05$ was considered statistically significant and $\mathrm{p}<0.001$ as highly significant, respectively.

\section{RESULTS}

\section{Behaviors scored in the EPM}

Open arm durations

The anxiety behavior following the administration of graded doses of the Ficus thoninigii leaf and the control diets was as follows:

- Control: $7.80 \pm 1.30 \mathrm{~s}$

- Low dose: $22.80 \pm 6.26 \mathrm{~s}$

- High dose: $22.20 \pm 4.76 \mathrm{~s}$

The open arm durations for both the low and high dose were significantly higher $(\mathrm{p}<0.001)$ compared to the control group (Fig. 1). However, the high-dose group did not differ when compared to the lowdose group of mice.

\section{Close arm entries}

The values of the closed arm entries following the administration of graded doses of $F$ thoningii and control diets were as follows:

- Control group: $5.60 \pm 1.14 / 5 \mathrm{~min}$

- Low dose: $4.80 \pm 0.83 / 5 \mathrm{~min}$

- High dose: $2.60 \pm 0.89 / 5 \mathrm{~min}$.

The low- and high-dose groups were significantly lower $(\mathrm{p}<0.01$ and p $<0.001$ ) compared to control (Fig. 2)

\section{Close arm durations}

The values for the closed arm durations among the different experimental groups were as follows:

- Control group: $112.40 \pm 2.30 \mathrm{~s}$

- Low dose: $73.00 \pm 9.74 \mathrm{~s}$

- High dose: $71.60 \pm 18.71 \mathrm{~s}$

In the EPM test for anxiety, the closed arm durations for the low- and high-dose groups were significantly lower $(\mathrm{p}<0.001)$ compared to

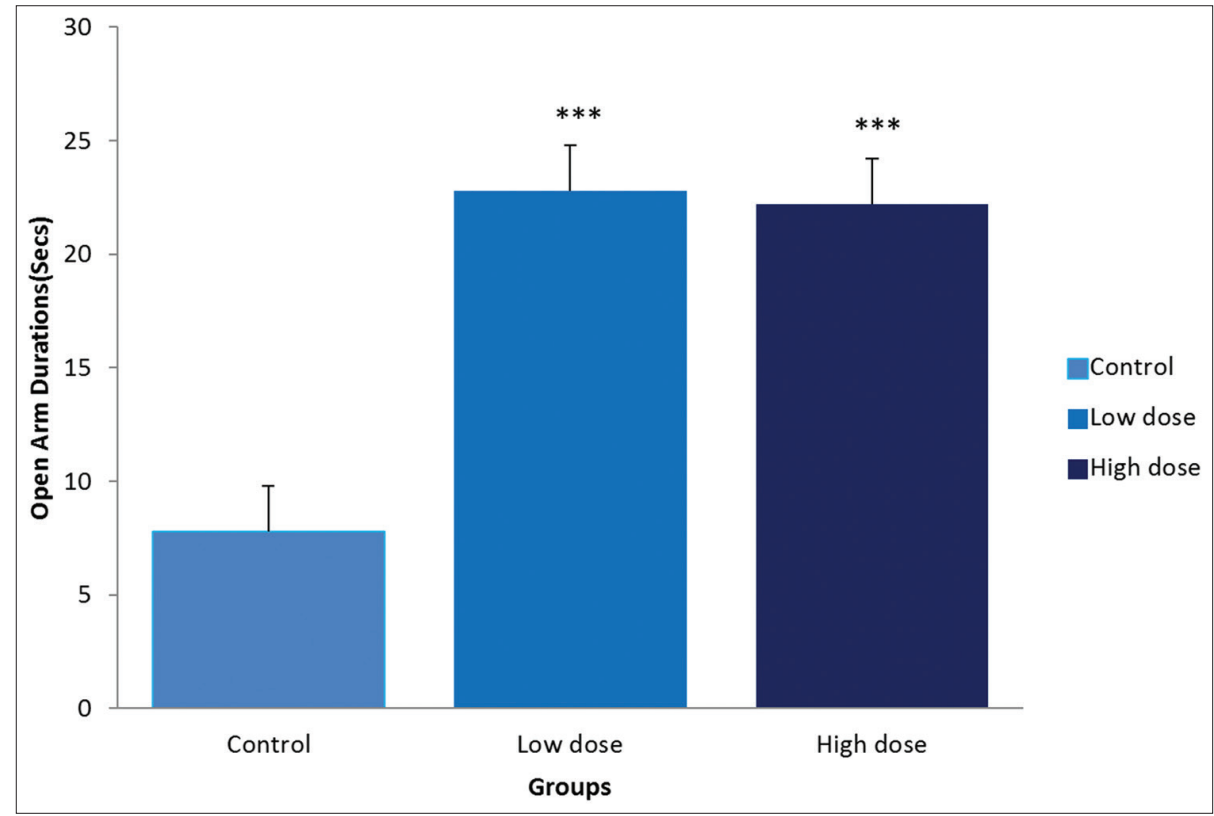

Fig. 1: Effects of the administration of Ficus thonningii diet on open arm durations in the elevated plus maze test of the different experimental groups. Values are mean \pm standard error of mean, $\mathbf{n = 1 0} * * * \mathbf{p}<0.001$ versus control 


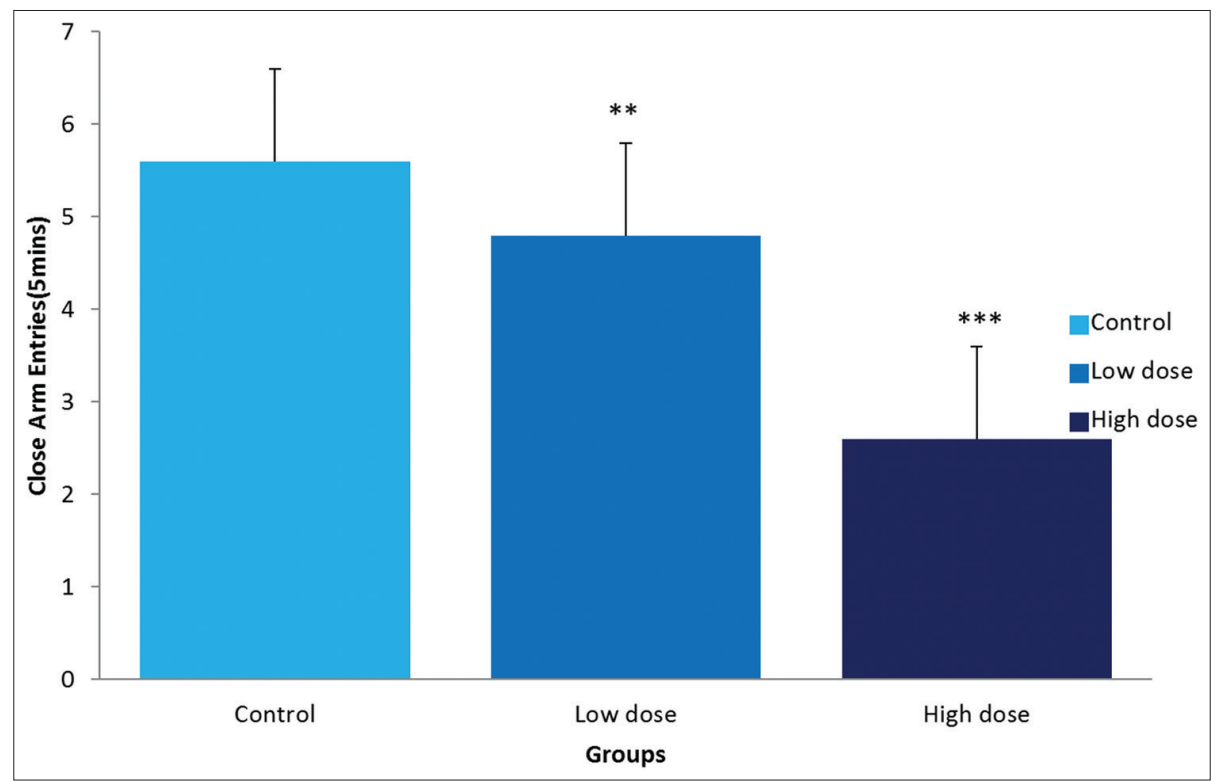

Fig. 2: Effects of administration of Ficus thonningii diet on closed arm entries in the elevated plus maze test of the different experimental groups. Values are mean \pm standard error of mean, $\mathbf{n}=10 . * * \mathbf{p}<0.01$ versus control; ${ }^{* * *} \mathbf{p}<0.001$ versus control

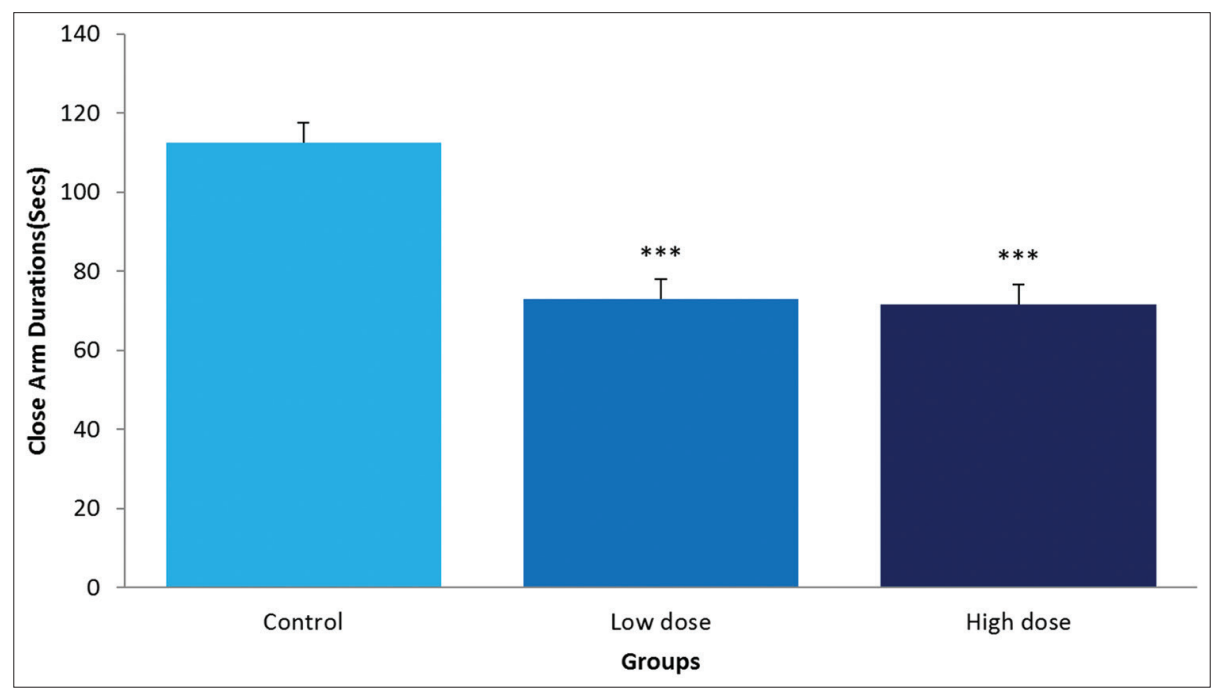

Fig. 3: Effects of administration of Ficus thonningii diet on closed arm durations in the elevated plus maze test of the different experimental groups. Values are mean \pm standard error of mean, $\mathbf{n}=10 . * * \mathbf{p}<0.001$ versus control

control (Fig. 3). However, there was no significant difference between the low- and high-dose groups.

\section{Head dips}

The frequencies of head dips among the different experimental groups were as follows:

- Control group: $3.00 \pm 1.00 / 5 \mathrm{~min}$

- Low dose: $5.40 \pm 1.14 / 5 \mathrm{~min}$

- High dose: $7.40 \pm 1.14 / 5 \mathrm{~min}$.

The low-dose group was significantly higher $(p<0.01)$ compared to control (Fig. 4). However, the value of the high-dose group was also significantly higher $(p<0.001)$ when compared to the control group of mice.

\section{Stretch-attend posture}

The frequencies of the stretch-attend posture between the three experimental groups were as follows:
- Control group: $8.60 \pm 1.14 / 5 \mathrm{~min}$

- Low dose: $4.80 \pm 1.30 / 5 \mathrm{~min}$

- High dose: $2.40 \pm 1.14 / 5 \mathrm{~min}$

The low- and high-dose groups were both significantly lower $(\mathrm{p}<0.01$ and $\mathrm{p}<0.001$ ) compared to control (Fig. 5).

\section{DISCUSSION}

The EPM is a widely used behavioral test for assessing antianxiety behavior in rodent [17]. It is an established and reliable test for detecting anxiolytic-like effect of agents [18,19]. In this study, behaviors, such as time spent in the open/close arm, frequencies of entry in the open/close arm, stretch-attend posture, and head dipping, were used to assess the level of anxiety in mice. A decrease in anxietylike behaviors characterized by reduced entry frequency into the close arm, increased open arm entry, and head dipping frequencies in the wild fig-treated groups implies the anxiogenic effect of $F$. thonningii. An increase in the duration of the entries into the open arms is regarded as 


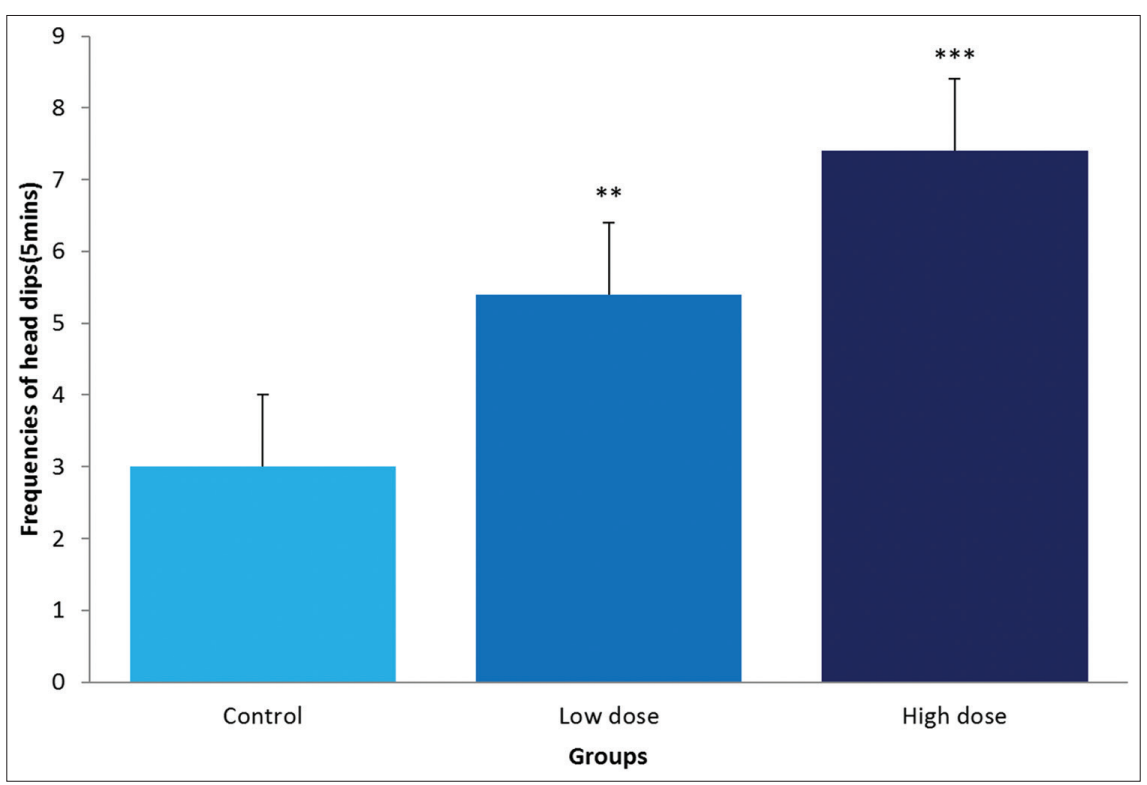

Fig. 4: Effects of administration of Ficus thonningii diet on head dips in the elevated plus maze test of the different experimental groups. Values are mean \pm standard error of mean, $n=10 . * p<0.01$ versus control; ${ }^{* * *} p<0.001$ versus contro

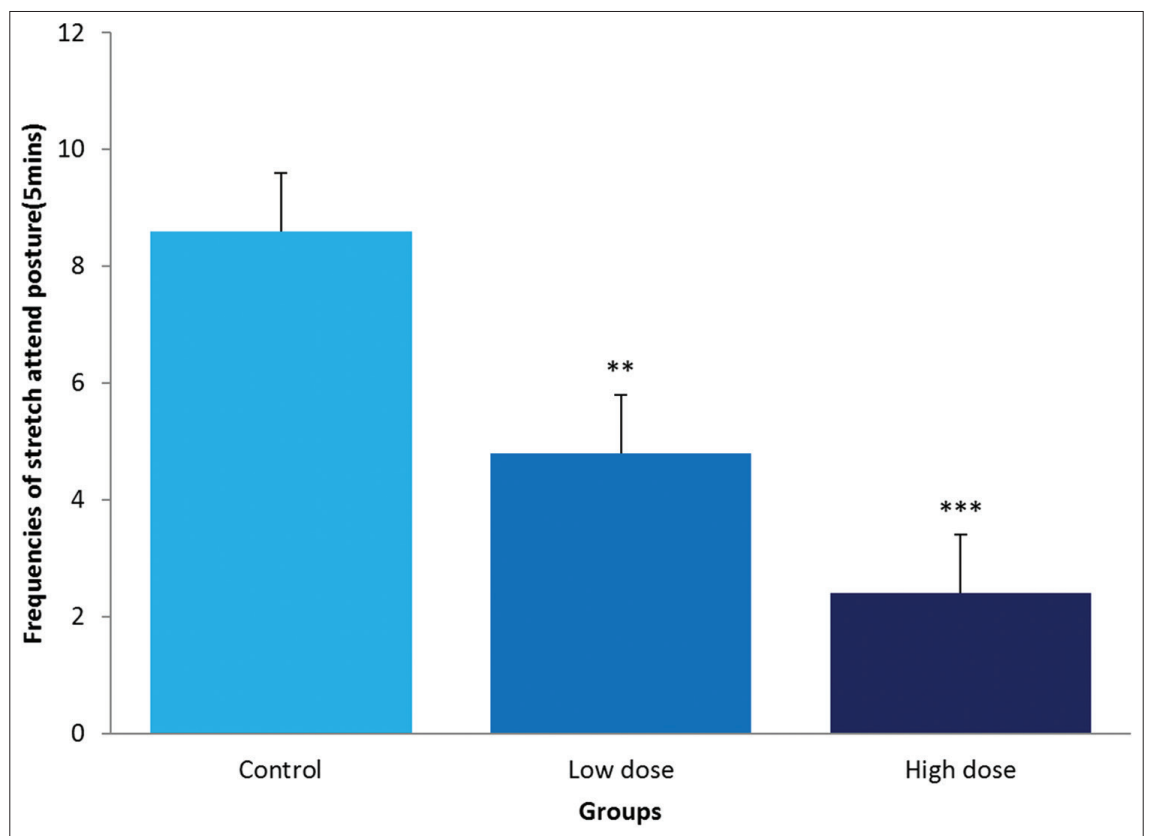

Fig. 5: Effects of administration of Ficus thonningii diet on frequencies of stretch attend posture in the elevated plus maze test of the different experimental groups. Values are mean \pm standard error of mean, $\mathbf{n}=10$. ${ }^{* *} \mathbf{p}<0.01$ versus control; ${ }^{* * *} \mathbf{p}<0.001$ versus control

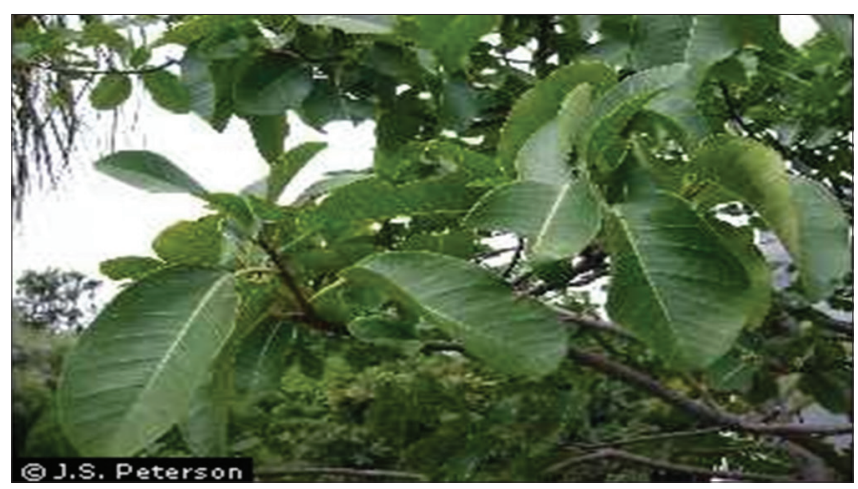

Fig. 6: The leaves and fruit of the common wild fig a powerful marker for an anxiolytic substance effect [20]. In this study, administration of $F$. thonningii remarkably decreases the level of anxiety in mice which was characterized by reduced entry and duration into the closed arm across the period of the study when compared to the control. Behaviors, such as grooming, stretch-attend posture, and head dipping, have also been demonstrated as credi'ble indices in measuring rodent response to stress $[17,21]$. Furthermore, striking decrease in anxiety-like response, such as SAP and head dipping frequencies, was observed with $F$. thonningii treatments. Increase in the duration and frequencies of the entries into the open arms in the EPM test had been confirmed as a potent sign of an anxiolytic substance effect [22]. Several researchers have reported that flavonoids exhibit a wide range of biological activities, such as antioxidant, anti-inflammatory, and antiangiogenic effects $[23,24]$. It is possible that the chemical components with antioxidant activities such as flavonoid play essential 
roles in the anxiolytic properties of $F$. thonningii leaf as observed in the study. This is in consonance with a report related to the anxiolytic effect of plant extracts $[25,26]$.

\section{CONCLUSION}

F. thonningii may prove effective in ameliorating anxiety-like behavior in mice. It would be worthwhile to explore the potential of this plant in the management/treatment of anxiety disorders.

\section{ACKNOWLEDGMENT}

I acknowledged Mr. and Mrs. B. A. Aduema and Miss Vivian for their support.

\section{CONFLICTS OF INTEREST}

I hereby write to confirm that there is no conflict of interest with respect to the publication of this piece.

\section{REFERENCES}

1. Ajayi AO. Antimicrobial nature and use of some medicinal plants in Nigeria. Afr J Biotech 2008;7:595-9.

2. Prelude JL. Medicinal Plants Database. http://www.metafro.be/prelude/ view_plant?pi $=06040.2011$

3. Schmidt E, Lutter M, McCleland W. Trees and shrubs of Mpumalanga and Kruger National Park. South Africa: Jacana; 2002. p. 80.

4. Njoronge GN, Kibunga JW. Herbal medicine acceptance, sources and utilization for diarrhea management in a cosmopolitan urban area (Thika, Kenya). Afr J Ecol 2007;45:65-70.

5. Cousins D, Huffman MA. Medicinal properties in the diets of gorillas: An ethno-pharmacological evaluation. Afr Study Monogr 2002; 23:65-89.

6. Igoli JO, Tor-Anyin TA, Usman SS, Oluma HO, Igoli NP. Folk medicines of the Beneu valley of Nigeria. In: Singh VK, Govil JN, Hashim S, Sing G, editors. Recent Progress in Medicinal Plants, Ethnomedicine and Pharmacognosy. Raleigh, NC: Science Technology Publishers; 2002. p. 327-38.

7. Alawa JP, Jokthan GE, Akut K. Ethnoveterinary medical practice for ruminants in the subhumid zone of northern Nigeria. Prev Vet Med 2002;54:79-90.

8. Arbonier MA. Trees, Shrubs and Lianas of West African Dry Zones. $2^{\text {nd }}$ ed. Netherlands: Margraf Publishers; 2004. p. 412.

9. Mali RG, MehtaAA. Areview on anthelmintic plants. Nat Prod Rad 2007; 7:466-75.

10. Gelfand M, Mavi S, Drummond RB, Ndemera B. The Traditional Medicinal Practitioner. His Principles of Practice and Pharmacopoeia. Gweru, Zimbabwe: Mambo Press; 1985. p. 411.

11. Tegbe TS, Adeyinka IA, Baye KD, Alawa JP. Evaluation of feeding graded levels of dried and milled Ficus thonningii leaves on growth performance, carcass characteristics and organ of weaner rabbits. Pak J Nutr 2006;5:548-50.

12. Byrne JH. Plasticity: New concepts, new challenges. In: Roediger HL, Dudai Y, Fitzpatrick SM, editors. Science of Memory: Concepts. New York: Oxford University Press; 2007. p. 77-82.

13. Mathieu G, Meissa D. Traditional leafy vegetables in Senegal: Diversity and medicinal uses. Afr J Tradit Complement Altern Med 2007; 4:469-75.

14. Wondimu T, Asfaw Z, Kelbessa E. Ethnobotanical study of medicinal plants around 'Dheeraa' town, Arsi Zone, Ethiopia. J Ethnopharmacol 2007; 112:152-61

15. Lister RG. Ethologically-based animal models of anxiety disorders. Pharmacol Ther 1990;46:321-40.

16. John S. Schematic Drawing of the Elevated plus Maze (EPM) Experiment for Behavior Tests with Rats. http://www.ed.wikipedia. org.2010.

17. Walf AA, Frye CA. The use of the elevated plus maze as an assay of anxiety-related behavior in rodents. Nat Protoc 2007;2:322-8.

18. He LH, Shi HM, Liu TT, Xu YC, Ye KP, Wang S, et al. Effects of extremely low frequency magnetic field on anxiety level and spatial memory of adult rats. Chin Med J (Engl) 2011;124:3362-6.

19. Kochenborger L, Levone BR, da Silva ES, Taschetto AP, Terenzi MG, Paschoalini MA, et al. The microinjection of a cannabinoid agonist into the accumbens shell induces anxiogenesis in the elevated plus-maze. Pharmacol Biochem Behav 2014;124:160-6.

20. Skelly MJ, Weiner JL. Chronic treatment with prazosin or duloxetine lessens concurrent anxiety-like behavior and alcohol intake: Evidence of disrupted noradrenergic signaling in anxiety-related alcohol use. Brain Behav 2014;4:468-83.

21. Pellow S, Chopin P, File SE, Briley M. Validation of open: Closed arm entries in an elevated plus-maze as a measure of anxiety in the rat. J Neurosci Methods 1985;14:149-67.

22. Puurunen K. The Effects of Pharmacotherapy and Training of Functional Recovery after Global and Cerebral Ischemia in Rats. Series of Reports, No 58. Kuopio: Department of Neuroscience and Neurology, University of Kuopio; 2001. p. 40.

23. Popovic-Milenkovic MT, Tomovic MT, Brankovic SR, Ljujic BT, Jankovic SM. Antioxidant and anxiolytic activities of Crataegus nigra Wald. Et kit. Berries. Acta Pol Pharm 2014;71:279-85.

24. Charkravarthi KK, Ramakrishna A, Nayaran RS. Effects of Glycyrrhiza glarbra root extract on learning and memory in wistar albino rats. Inter J Biol Med Res 2012;3:2059-64.

25. Komaki A, Hoseini F, Shahidi S, Baharlouei N. Study of the effect of extract of Thymus vulgaris on anxiety in male rats. J Tradit Complement Med 2016;6:257-61.

26. Suprila R, Himani A. CNS depression, sedative and anxiolytic activity of ethanol exract of fruit of piper Chiba revealed after neuropharmacological screening. Int J Pharm Pharm Sci 2014;6:186-9. 